\title{
Priming the Cow for Mobilization in the Periparturient Period: Effects of Supplementing the Dry Cow with Saturated Fat or Linseed
}

\author{
J. B. Andersen, ${ }^{* 1}$ C. Ridder, ${ }^{*} \dagger$ and T. Larsen ${ }^{\star}$ \\ *University of Aarhus, Faculty of Agricultural Sciences, Dept. Animal Health, Welfare and Nutrition, PO Box 50, DK-8830 Tjele, Denmark \\ †Lattec I/S, Slangerupgade 69, DK-3400 Hillerød, Denmark
}

\begin{abstract}
High-producing dairy cows experience negative energy balance in early lactation. Dry-cow feeding management will affect the performance and metabolic status of dairy cows in the following early lactation. The present study evaluates dry-cow feeding strategies for priming lipid metabolism in the dairy cow to overcome the metabolic challenges in the following early lactation. Five weeks before expected calving, 27 cows were assigned to 1 of 3 isonitrogenous and isoenergetic dietary treatments: a low-fat control diet (dry-control); a high saturated fat diet (dry-HSF); and a high linseed diet (dry-HUF). The cows were fed the same TMR lactation diet after calving. The treatments were evaluated by performance and metabolic parameters in blood and liver. The cows fed dry-HSF and dry-HUF had significantly greater plasma nonesterified fatty acid concentrations compared with dry-control, and the dry-HUF cows had the greatest C18:3 concentrations in plasma in the prepartum period. Further, the cows fed dryHSF and dry-HUF diets had a tendency for the greatest capacity for incomplete $\beta$-oxidation of fatty acids in the liver in wk 3 prepartum. The plasma cholesterol concentration was greatest for cows fed dry-HSF in the prepartum period compared with those fed dry-control and dry-HUF. The cows fed dry-HSF had the lowest plasma nonesterified fatty acid and liver fat concentrations in early lactation compared with the cows fed dry-control and dry-HUF. Data in the literature and the present experiment indicate that supplementing dry cows with a saturated fatty acid source is a positive strategy for priming dairy cows for body fat mobilization in the following early lactation.
\end{abstract}

Key words: dry-cow feeding management, metabolic status, transition period, liver

Received June 12, 2007.

Accepted November 3, 2007.

${ }^{1}$ Corresponding author: jens.bechandersen@agrsci.dk

\section{INTRODUCTION}

The high-yielding dairy cow experiences massive metabolic changes during the transition from the dry period in late gestation to the onset of copious milk secretion in early lactation (Bell, 1995; Ingvartsen and Andersen, 2000). The periparturient period is thus associated with an increased risk of metabolic- and production-related diseases, arising because of inadequate metabolic homeorhetic adaptation (Ingvartsen and Andersen, 2000; Ingvartsen et al., 2003; Friggens et al., 2004). It is generally accepted that nutritional management in the dry period affects the metabolic status in the subsequent lactation, and that most dairy cows mobilize body reserves in early lactation. Previously, we presented the idea that feeding a high-fat ration in the dry period could prime the cow to adapt to body fat mobilization in the following early lactation (Friggens et al., 2004). This strategy is based on the principle that feeding a high-fat ration in the dry period could increase circulating concentrations of NEFA, thereby increasing fatty acid (FA) uptake into the liver for preadaptation of hepatic long-chain fatty acid (LCFA) metabolism. The origination of this idea was inspired by data from the study of Grum et al. (1996b), and has been discussed in the reviews by Friggens et al. (2004) and Drackley and Andersen (2006).

Grum et al. (1996b) demonstrated that dry cows fed a relatively large amount of fat (high in palmitic acid and oleic acid) had a slightly increased $\beta$-oxidation capacity of LCFA in the liver, and a smaller liver triacylglycerol (TAG) concentration in the following early lactation. Other experiments have demonstrated that an increased supply of LCFA to the liver can stimulate the hepatic capacity of LCFA $\beta$-oxidation (Osmundsen et al., 1991; Grum et al., 1996a; Cadorniga-Valino et al., 1997; Mashek and Grummer, 2003). Studies with monogastric animals have demonstrated that specific FA such as linolenic acid (C18:3) have a more positive effect on the $\beta$-oxidation capacity of LCFA and a reduced TAG concentration in the liver compared with saturated LCFA (Ide et al., 1996; Berge et al., 1999). Further, it has been demonstrated that intravenous infusion of 
linseed oil to fasted dairy cows lowered plasma concentration of NEFA and BHBA, and tended to lower the hepatic TAG concentration compared with infusion of tallow (Mashek et al., 2005). The explanation of the effect of C18:3 may relate to the stimulating effects on the peroxisomal proliferator activated receptor mRNA (PPAR $\alpha$ mRNA) in the liver tissue. Studies with rats have shown that PPAR $\alpha$ stimulates the amount of peroxisomes and carnitine palmitoyltransferase I (CPT-1) mRNA and generally increases the activity of hepatic key enzymes for the LCFA $\beta$-oxidation process (Schoonjans et al., 1996; Kerner and Hoppel, 2000). Therefore, it can be argued that feeding a large amount of C18:3 in the dry period should be the ideal strategy for priming the cow for mobilization in the following early lactation.

Ruminants are different, however, from most monogastric animals concerning digestion and with regard to hepatic lipid metabolism (Chilliard, 1993; Grum et al., 1994). As an example, only about $10 \%$ of C18:3 will bypass the rumen (Hagemeister et al., 1991). Different ways of bypassing unsaturated LCFA (polyunsaturated FA, PUFA) from the rumen have been evaluated, and it has been shown that whole linseed is a good source of C18:3 for cattle (Reklewska et al., 2002; Lessard et al., 2003; Petit, 2003). Furthermore, ruminant experiments have demonstrated that the effects and mechanisms of different LCFA, on hepatic carbohydrate and lipid metabolism, seem neither to be simple nor identical (Mashek et al., 2002; Mashek and Grummer, 2003). Combining results from in vitro, infusion, and feeding experiments (Mashek et al., 2002, 2005; Petit, 2002, 2003; Mashek and Grummer, 2003), it seems likely that not only C18:3, but also oleic acid (C18:1), linoleic acid (C18:2), and eicosapentaenoic acid (C20:5) are beneficial to the hepatic carbohydrate and lipid metabolism of dairy cows. No previously published experiments have demonstrated the effects of feeding different fat sources in the dry period on priming the dairy cow for mobilization in the periparturient period. The objective of the present experiment was to determine the effects of feeding linseed or a saturated fat source in the dry period on priming the dairy cow for mobilization of body fat in the periparturient period. Changes in BW, BCS, several blood metabolites, liver fat metabolism, and concentration of liver glycogen were followed as indicators of metabolic status and adaptive changes in the periparturient period (Andersen et al., 2002b, 2004).

\section{MATERIALS AND METHODS}

\section{Cows, Diets, and Experimental Design}

The experimental procedures were conducted under the protocols approved by the Danish Animal Experi- ments Inspectorate and complied with the Danish Ministry of Justice Law no. 386 (June 6, 1991) and Law no. 433 (May 31, 2000) and related Government orders concerning animal experimentation and care of experimental animals.

A homogeneous group of 29 Danish Holstein dairy cows (18 primiparous and 11 multiparous) were selected among the cows with the greatest merit for milk yield and good health records (i.e., treatment frequency and days open in previous lactation) in the dairy herd of the Danish Institute of Agricultural Sciences, Research Center Foulum. The cows were dried off 8 wk before expected calving and were assigned to 1 of 3 dietary treatments. Diet formulation is shown in Table 1, and the allocated TMR and added feed components are shown in Table 2 . The dry period was divided into 2 periods. The first period was from wk -8 until wk -6 , and the second period was from wk -5 until calving. All cows received $10.5 \mathrm{~kg}$ (DM) daily of a low-fat drycow diet (TMR Dry) that was supplemented with 0.6 $\mathrm{kg}$ (DM) of toasted soy meal in the first period. The second part of the dry period, the diets were based on TMR Dry supplemented with toasted soy meal (drycontrol), TMR Dry supplemented with toasted soy meal and a commercial saturated fat powder (Lipitec Bovi LM, NLM Combineering ApS, Vantinge, Denmark) to increase saturated FA in the diet (dry-HSF), or TMR Dry supplemented with whole linseed to increase unsaturated FA in the diet (dry-HUF). The fat and LCFA compositions of the saturated fat powder and linseed are shown in Table 3.

The diets in the dry period were fed in restricted amounts as shown in Table 2. All dry period diets were formulated to provide an adequate amount of energy and protein for a neutral body weight gain, and were sufficient for the fetus according to the Danish recommendations for dry cows (Strudsholm et al., 1999). The diets were, however, very different in fat amount and FA profile as shown in Tables 2 and 3. After parturition, all cows received the same lactation diet (TMR Lact) for ad libitum intake. A daily feed refusal of $5 \%$ or more was the aim for ad libitum fed TMR Lact. The lactation diet was formulated to fulfill the requirements of the Danish norms (Strudsholm et al., 1999). The feed rations, both in the dry period and in the lactation period, were fed twice a day at 0800 and $1400 \mathrm{~h}$. The cows were kept in a tie-stall barn bedded with barley straw twice daily, and the cows had free access to water. Cows were milked twice daily at 0430 and $1530 \mathrm{~h}$, and milk yield was recorded at the morning and afternoon milking twice weekly. Dry matter intake was measured daily, and BW was measured weekly on a fixed day of the week both prepartum and postpartum. Because of logistic 
Table 1. Ingredient composition of diets and chemical composition and calculated energy content of diets and feed supplements

\begin{tabular}{|c|c|c|c|c|c|}
\hline \multirow[b]{2}{*}{ Item } & \multicolumn{2}{|c|}{ Diet $^{1}$} & \multirow{2}{*}{$\begin{array}{c}\text { Saturated } \\
\text { fat }\end{array}$} & \multirow[b]{2}{*}{ Linseed } & \multirow[b]{2}{*}{ Soymea } \\
\hline & TMR Dry & TMR Lact & & & \\
\hline \multicolumn{6}{|l|}{ Ingredient (\% of DM) } \\
\hline Corn silage & 63.8 & 53.8 & & & \\
\hline Grass silage & & 20.9 & & & \\
\hline Barley straw & 18.7 & 2.4 & & & \\
\hline Rolled barley & 3.0 & 4.0 & & & \\
\hline Sugar beet pulp & 5.4 & 5.7 & & & \\
\hline Rapeseed cake & & 6.1 & & & \\
\hline Soy meal, toasted & 3.9 & 2.9 & & & \\
\hline Sugar beet molasses & 4.0 & 3.4 & & & \\
\hline \multicolumn{6}{|l|}{ Composition (\% of DM) } \\
\hline Crude fat & 2.1 & 3.3 & 96.0 & 40.9 & 2.9 \\
\hline $\mathrm{NDF}$ & 41.2 & 34.4 & 0 & 14.0 & 7.4 \\
\hline Sugar & 4.5 & 5.4 & 0 & 2.6 & 9.6 \\
\hline Starch & 20.8 & 18.6 & 0 & 5.4 & 5.8 \\
\hline $\mathrm{CP}$ & 10.9 & 16.2 & 0 & 23.2 & 57.2 \\
\hline Net energy, $\mathrm{SFU}^{2} / \mathrm{kg}$ of $\mathrm{DM}$ & 0.59 & 0.87 & 2.78 & 1.67 & 1.41 \\
\hline
\end{tabular}

${ }^{1}$ TMR Dry $=$ dry period feed ration; TMR Lact $=$ lactation feed ration.

${ }^{2}$ One Scandinavian Feed Unit (SFU) $=7,890 \mathrm{~kJ}$ of net energy/kg of DM (Strudsholm et al., 1997).

challenges, the cows were not weighed in wk -1 (the week before calving). Body condition score was measured in wk -5 , at calving, and in wk 5 after calving using a scale from 1 to 5 , including half points, where $1=$ thin and $5=$ extremely fat (Kristensen, 1986).

One cow fed dry-control had severe metritis and mastitis in the first week of lactation, and 1 cow fed dry-
HUF had Escherichia coli mastitis in the first week of lactation. These 2 cows were excluded from the experiment. Consequently, the distribution of cows in the 3 experimental treatments was dry-control: 5 primiparous and 4 multiparous; dry-HSF: 6 primiparous and 4 multiparous; and dry-HUF: 5 primiparous and 3 multiparous.

Table 2. Ingredient and chemical composition of feed supplements and diets containing low fat (dry-control), high saturated fat (dry-HSF), or high unsaturated fat (dry-HUF) in the dry period, and TMR for the dry period (TMR Dry) and lactation period (TMR Lact)

\begin{tabular}{|c|c|c|c|c|}
\hline \multirow[b]{2}{*}{ Item } & \multicolumn{3}{|c|}{ Dry period (wk -5 to calving) } & \multirow{2}{*}{$\frac{\text { Lactation }}{\text { All cows }^{2}}$} \\
\hline & Dry-control $^{1}$ & Dry-HSF ${ }^{1}$ & Dry-HUF ${ }^{1}$ & \\
\hline \multicolumn{5}{|l|}{ Offered feed (kg DM) } \\
\hline TMR Dry & 10.0 & 7.9 & 7.9 & \multirow{5}{*}{ Ad libitum } \\
\hline TMR Lact & - & - & - & \\
\hline Saturated $\mathrm{fat}^{3}$ & - & 0.6 & - & \\
\hline Linseed & - & - & 1.5 & \\
\hline Soy meal, toasted & 0.6 & 0.6 & - & \\
\hline \multicolumn{5}{|l|}{ Composition $^{4}$ (in \% of DM) } \\
\hline Crude fat & 2.1 & 8.1 & 7.9 & 3.3 \\
\hline $\mathrm{CP}$ & 13.4 & 13.1 & 12.8 & 16.2 \\
\hline Sugar & 4.8 & 4.5 & 4.2 & 5.4 \\
\hline Starch & 20.0 & 18.5 & 18.5 & 18.6 \\
\hline NDF & 39.4 & 36.4 & 37.1 & 34.4 \\
\hline Net energy, $\mathrm{SFU}^{5} / \mathrm{kg}$ of $\mathrm{DM}$ & 0.61 & 0.64 & 0.65 & 0.87 \\
\hline
\end{tabular}

${ }^{1}$ All cows received $100 \mathrm{~g}$ of dry-cow mineral blend, $30 \mathrm{~g}$ of vitamin mix, and $100 \mathrm{~g}$ of feed urea daily to fulfill requirements for minerals, vitamins, and protein according to Strudsholm et al. (1999).

${ }^{2} \mathrm{All}$ cows received $100 \mathrm{~g}$ of limestone, $150 \mathrm{~g}$ of mineral blend, $30 \mathrm{~g}$ of vitamin mix, and $100 \mathrm{~g}$ of feed urea daily to fulfill requirements for minerals, vitamins, and protein according to Strudsholm et al. (1999).

${ }^{3}$ Lipitec Bovi LM, NLM Combineering ApS, Vantinge, Denmark. Spray-dried vegetable fat powder high in C16:0 and C18:0 including 2\% lecithin (see Table 3 for fatty acid analysis).

${ }^{4}$ Calculated relative to TMR Dry plus added feed components and TMR Lact.

${ }^{5}$ One Scandinavian Feed Unit (SFU) = 7,890 kJ of net energy/kg of DM (Strudsholm et al., 1997). 
Table 3. Fatty acid composition and daily intake of fat supplementation used in the high saturated fat and high unsaturated fat diets from wk -5 to calving

\begin{tabular}{lccccc}
\hline & \multicolumn{2}{c}{ Saturated fat ${ }^{1}$ (dry-HSF diet) } & & \multicolumn{2}{c}{ Linseed (dry-HUF diet) } \\
\cline { 2 - 3 } \cline { 5 - 6 } Content & \% of DM & Intake, g ${ }^{2}$ & & \% of DM & Intake, g \\
\hline Crude fat, \% of DM & 96.0 & 576.1 & & 40.9 & 613.4 \\
Fatty acids, \% of DM & 91.0 & 547.2 & & 38.7 & 581.1 \\
& \% of total fatty acids & & & \% of total fatty acids \\
C14:0 & 1.3 & 7.0 & & 0.05 & 0.3 \\
C16:0 & 47.4 & 260.6 & & 5.7 & 32.9 \\
C18:0 & 42.0 & 229.8 & & 4.0 & 23.0 \\
C18:1 & 5.7 & 31.0 & & 16.1 & 93.5 \\
C18:2 & 1.8 & 10.1 & & 13.4 & 78.1 \\
C18:3 & 0.1 & 0.6 & & 60.0 & 348.8 \\
\hline
\end{tabular}

${ }^{1}$ Lipitec Bovi LM, NLM Combineering ApS, Vantinge, Denmark. Spray-dried vegetable fat powder high in $\mathrm{C} 16: 0$ and $\mathrm{C} 18: 0$ including $2 \%$ lecithin.

${ }^{2}$ Calculated by multiplying the content of fat sources by the total daily supplemented fat sources $(0.6 \mathrm{~kg}$ DM of saturated fat and $1.5 \mathrm{~kg}$ DM of linseed).

\section{Sampling and Analysis of Feed and Milk}

The TMR components and added feed sources were sampled and analyzed as described by Ingvartsen et al. (2001), and the average chemical composition is presented in Tables 1 and 2 . Based on the daily feed intakes, an average daily feed intake was calculated on a weekly basis. Fat in the saturated fat and linseed was extracted with diethyl ether after acid hydrolysis, and FA in Stoldt fat extract was determined as described by Jørgensen et al. (2000).

Proportional milk samples were obtained from each milking, at the day of milk yield recording, and stored at $5^{\circ} \mathrm{C}$ until analysis. Analyses for milk fat, protein,

Table 4. The effect of diets containing low fat (dry-control), high saturated fat (dry-HSF), or high unsaturated fat (dry-HUF) in the dry period on feed intake, BCS, BW, and milk production

\begin{tabular}{|c|c|c|c|c|c|c|c|}
\hline \multirow[b]{2}{*}{ Parameter } & \multicolumn{3}{|c|}{ Diet } & \multirow[b]{2}{*}{$\mathrm{SE}$} & \multicolumn{3}{|c|}{$P$-value ${ }^{1}$} \\
\hline & Dry-control & Dry-HSF & Dry-HUF & & $\mathrm{T}$ & Wk & $\mathrm{T} \times \mathrm{Wk}$ \\
\hline \multicolumn{8}{|l|}{ DMI, kg/d } \\
\hline Prepartum $^{2}$ & 11.0 & 9.4 & 9.9 & 0.6 & 0.18 & 0.12 & 0.23 \\
\hline Postpartum $^{3}$ & 18.3 & 18.1 & 17.5 & 1.3 & 0.12 & $<0.0001$ & 0.23 \\
\hline \multicolumn{8}{|l|}{ Net energy, SFU ${ }^{4}$} \\
\hline Prepartum & 6.9 & 7.4 & 7.4 & 0.1 & 0.2 & 0.12 & 0.33 \\
\hline Postpartum & 16.0 & 15.8 & 15.2 & 0.5 & 0.2 & $<0.0001$ & 0.33 \\
\hline \multicolumn{8}{|l|}{ BCS, units } \\
\hline Prepartum, wk -5 & 3.7 & 3.4 & 3.8 & 0.2 & 0.10 & & \\
\hline Calving, wk 0 & 3.2 & 3.2 & 3.5 & 0.1 & 0.30 & & \\
\hline Postpartum, wk 5 & 2.7 & 2.6 & 2.8 & 0.2 & 0.76 & & \\
\hline \multicolumn{8}{|l|}{$\mathrm{BW}, \mathrm{kg}$} \\
\hline Prepartum, wk -5 & 651 & 624 & 626 & 39 & 0.29 & & \\
\hline Calving, ${ }^{5}$ wk 0 & 603 & 584 & 578 & 24 & 0.50 & & \\
\hline Postpartum, wk 5 & 583 & 568 & 558 & 44 & 0.54 & & \\
\hline Milk, kg/d & 34.8 & 36.2 & 35.3 & 1.9 & 0.84 & $<0.0001$ & 0.82 \\
\hline $\mathrm{ECM}, \mathrm{kg} / \mathrm{d}$ & 38.2 & 39.9 & 39.4 & 1.7 & 0.73 & $<0.0001$ & 0.61 \\
\hline Fat, $\%$ & 4.33 & 4.45 & 4.48 & 0.16 & 0.78 & $<0.0001$ & 0.83 \\
\hline Protein, ${ }^{6} \%$ & 3.35 & 3.32 & 3.42 & $0.02^{7}$ & 0.27 & $<0.0001$ & 0.59 \\
\hline Lactose, \% & 4.81 & 4.85 & 4.76 & 0.03 & 0.15 & $<0.0001$ & 0.10 \\
\hline $\mathrm{SCC},{ }^{6} \times 1,000$ cells $/ \mathrm{mL}$ & 69.4 & 78.3 & 84.8 & $0.26^{7}$ & 0.85 & $<0.0001$ & $<0.0001$ \\
\hline
\end{tabular}

${ }^{1} \mathrm{~T}=$ treatment in dry period; $\mathrm{Wk}=$ week around calving.

${ }^{2} \mathrm{LSM}$ of wk -5 to -1 .

${ }^{3} \mathrm{LSM}$ of wk 0 to 5 .

${ }^{4}$ One Scandinavian Feed Unit (SFU) $=7,890 \mathrm{~kJ}$ of net energy/kg of DM (Strudsholm et al., 1997).

${ }^{5}$ Weight after calving (without calf).

${ }^{6}$ Geometric mean of log-transformed data.

${ }^{7} \mathrm{SE}$ based on log-transformed data. 
Table 5. The effect of diets containing low fat (dry-control), high saturated fat (dry-HSF) or high unsaturated fat (dry-HUF) in the dry period on long-chain fatty acids in plasma at wk -3 and 3 around parturition

\begin{tabular}{lcccccc}
\hline $\begin{array}{l}\text { Fatty acid, } \\
\text { \% of total } \\
\text { fatty acids }\end{array}$ & Time, wk & Dry-control & Dry-HSF & Dry-HUF & SE & \multicolumn{2}{c}{ T $^{1}$} \\
\cline { 2 - 6 } C16:0 & -3 & $13.3^{\mathrm{b}}$ & $18.2^{\mathrm{c}}$ & $11.1^{\mathrm{a}}$ & 0.5 & $<0.0001$ \\
& 3 & 12.7 & 11.5 & 11.8 & 0.5 & 0.32 \\
$\mathrm{C} 18: 0$ & -3 & $19.8^{\mathrm{a}}$ & $19.5^{\mathrm{a}}$ & $24.6^{\mathrm{b}}$ & 0.5 & $<0.0001$ \\
& 3 & 15.5 & 16.0 & 15.3 & 0.5 & 0.61 \\
$\mathrm{C} 18: 1$ & -3 & $11.8^{\mathrm{a}}$ & $20.9^{\mathrm{c}}$ & $15.5^{\mathrm{b}}$ & 1.0 & 0.02 \\
& 3 & 17.1 & 14.9 & 15.6 & 1.0 & 0.33 \\
$\mathrm{C} 18: 2$ & -3 & $38.0^{\mathrm{b}}$ & $24.5^{\mathrm{a}}$ & $26.2^{\mathrm{a}}$ & 1.4 & $<0.0001$ \\
& 3 & 38.0 & 39.2 & 39.6 & 1.4 & 0.72 \\
$\mathrm{C} 18: 3$ & -3 & $2.5^{\mathrm{a}}$ & $2.2^{\mathrm{a}}$ & $10.1^{\mathrm{b}}$ & 0.3 & $<0.0001$ \\
& 3 & 6.0 & 7.0 & 7.1 & 0.3 & 0.02 \\
$\mathrm{C} 20: 5$ & -3 & $0.6^{\mathrm{a}}$ & $0.9^{\mathrm{a}}$ & $1.3^{\mathrm{b}}$ & 0.1 & 0.007 \\
& 3 & 1.0 & 1.0 & 1.2 & 0.1 & 0.13 \\
$\mathrm{C} 22: 6$ & -3 & $0.08^{\mathrm{b}}$ & $0.03^{\mathrm{a}}$ & $0.07^{\mathrm{b}}$ & 0.01 & 0.002 \\
& 3 & 0.08 & 0.07 & 0.08 & 0.01 & 0.46 \\
\hline
\end{tabular}

${ }^{\mathrm{a}-\mathrm{c}}$ Means with different superscripts within a row indicate a $P$-value $<0.05$.

${ }^{1} \mathrm{~T}=$ treatment in dry period.

lactose, and SCC were performed on a CombiFoss 4000 (Foss Electric A/S, Hillerød, Denmark). Milk composition and milk yield from the 2 weekly sample sessions were used to calculate an average weekly content in milk and ECM as described by Sjaunja et al. (1990).

\section{Sampling and Analysis of Blood}

Blood samples were obtained from a jugular vein approximately $5 \mathrm{~h}$ after the morning feeding on Wednesdays from wk 5 before to wk 6 after calving. Blood was sampled in Vacutainer tubes (Vacutainer, Becton Dickinson Vacutainer Systems, Plymouth, UK) containing sodium heparin as an anticoagulant and kept on ice. The blood samples were centrifuged within 60 min at $4^{\circ} \mathrm{C}$ for $20 \mathrm{~min}$ at $2,000 \times g$. The plasma was collected and frozen at $-20^{\circ} \mathrm{C}$ until further analysis. Blood plasma samples were analyzed for NEFA, glucose, BHBA, plasma urea nitrogen (PUN), calcium, aspartate aminotransferase (AST), $\gamma$-glutamyl transferase (GGT), cholesterol, and insulin.

Blood plasma BHBA, NEFA, and glucose were determined according to methods described by Nielsen et al. (2007). The PUN analyses were based on the Rochrame (1967) enzyme reaction. Total calcium was determined using complex formation with o-cresolftalein. Aspartate aminotransferase was determined kinetically as a decrease in absorption (340 nm); and GGT was assessed according to Shaw et al. (1983). Plasma cholesterol was determined by the colorimetric standard procedure. All analyses were performed using an auto analyzer, $\mathrm{AD}$ VIA 1650 Chemistry System (Bayer Corporation, Tarrytown, NY). The intraassay variation (coefficient of variation, \%) and interassay variation (coefficient of variation, \%) were $<5 \%$ for low and high controls for all metabolites. Plasma concentrations of insulin were determined using a noncompetitive time-resolved immunofluorometric assay of the sandwich type. The timeresolved fluorescence from europium was read following chelation with an enhancement solution (Wallac, Oy, Finland). This analysis has been described in detail by Mashek et al. (2001). Five cows in each experimental group were randomly chosen, and plasma samples from wk -3 and wk 3 around calving were analyzed for LCFA in Stoldt fat extract as described by Jørgensen et al., 2000).

\section{Sampling and Analysis of Liver}

Liver biopsies were taken in wk $-3,2$, and 5 around calving. Liver biopsies $(6 \times 20-\mathrm{mg}$ biopsies $)$ were obtained through an incision on the right side of the cow at the 10th intercostal, where it crossed a line from midhumerus to tuber coxae. Before taking the biopsies, a $5 \times 5 \mathrm{~cm}$ area was shaved and disinfected, whereupon $5 \mathrm{~mL}$ of local anesthesia (Hostacain Vet, 2\%; Intervet, Skovlunde, Denmark) was given. After a minimum of $10 \mathrm{~min}, \mathrm{a} 1 / 2-\mathrm{cm}$ incision in the skin was made. Liver biopsies were taken from this incision using a Manan Automatic Biopsy System (14 gauge $\times 17 \mathrm{~mm}$ notch; Marmon/MDTech, Gainesville, FL). The biopsies were immediately frozen in liquid nitrogen and transported to the laboratory, where the biopsies were stored at $-80^{\circ} \mathrm{C}$ until analyzed.

Two liver biopsies (approximately $40 \mathrm{mg}$, wet weight) were weighed directly from $-80^{\circ} \mathrm{C}$ into $2 \mathrm{~mL}$ of ice-cold 

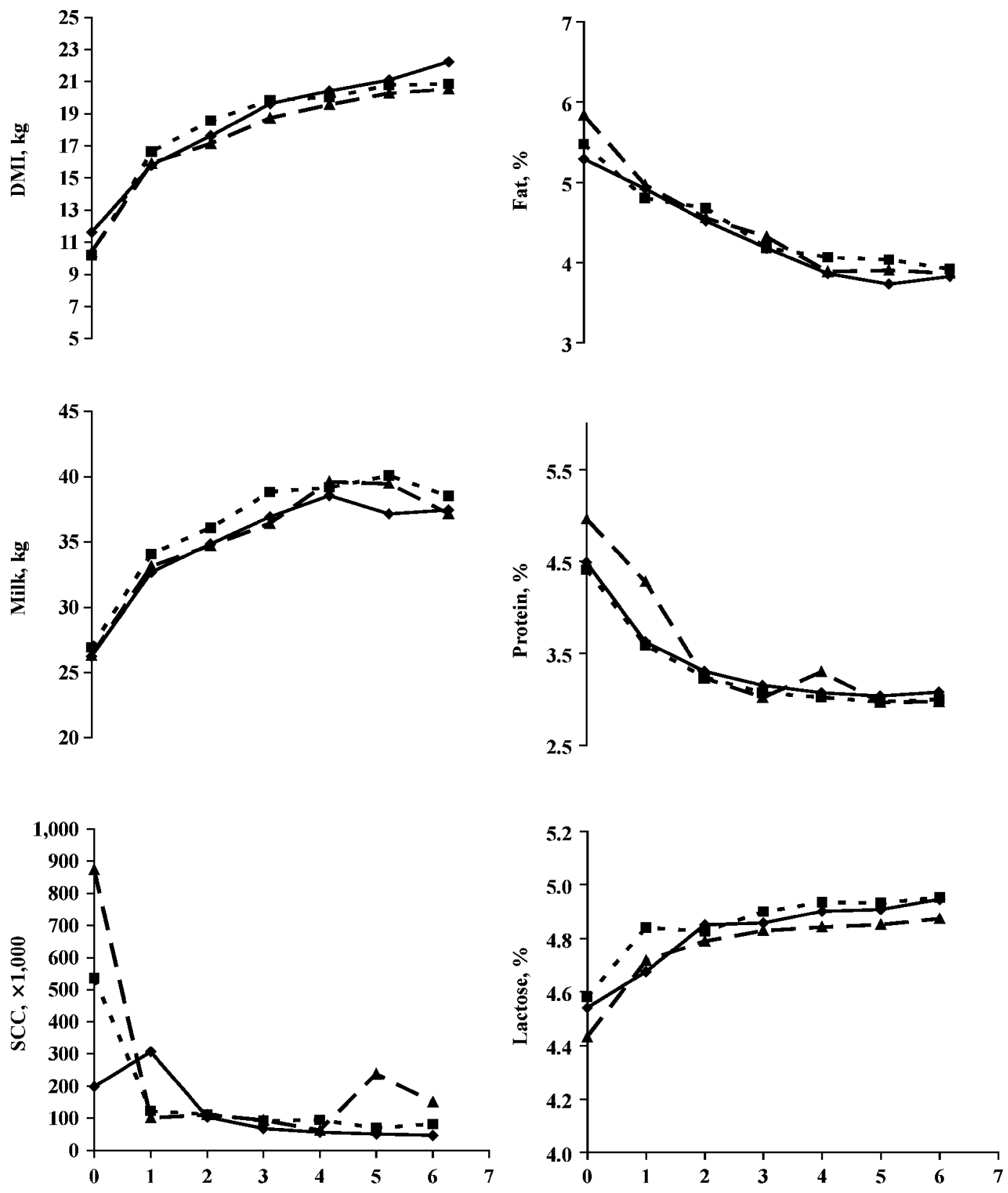

Week relative to parturition

Figure 1. Changes in DMI, milk yield, SCC, milk fat content, milk protein, and milk lactose content. The dairy cows were followed during the period between calving and $6 \mathrm{wk}$ after parturition by weekly samplings. Treatments were low-fat feeding in the dry period (drycontrol: ——), high saturated fat feeding in the dry period (dry-HSF: ——_ _ ) or high unsaturated fat feeding in the dry period (dryHUF: $--\boldsymbol{\Delta}--)$. See Table 4 for statistical tests.

PBS and kept on ice until homogenization for $30 \mathrm{~s}$ with an ultrasound sonicator (High Intensity Ultrasonic Processor, VC130, Sonics \& Materials, Inc., Newton, CT). The homogenate was centrifuged at $4^{\circ} \mathrm{C}$ for $10 \mathrm{~min}$ at 2,000 $\times \mathrm{g}$. A representative sample of the supernatant was analyzed for TAG, total protein, and glycogen. The analysis was based on an enzymatic colorimetric com- mercial kit modified to fit small tissue samples and performed on an auto analyzer, ADVIA 1650 Chemistry System (Bayer Corporation).

Complete $\left(\mathrm{CO}_{2}\right)$ and incomplete (ketogenesis) $\beta$-oxidation of $\left[1-{ }^{14} \mathrm{C}\right]$ palmitate were used as an estimate of the hepatic capacity for LCFA $\beta$-oxidation. The liver biopsies were used with no further preparation, as de- 

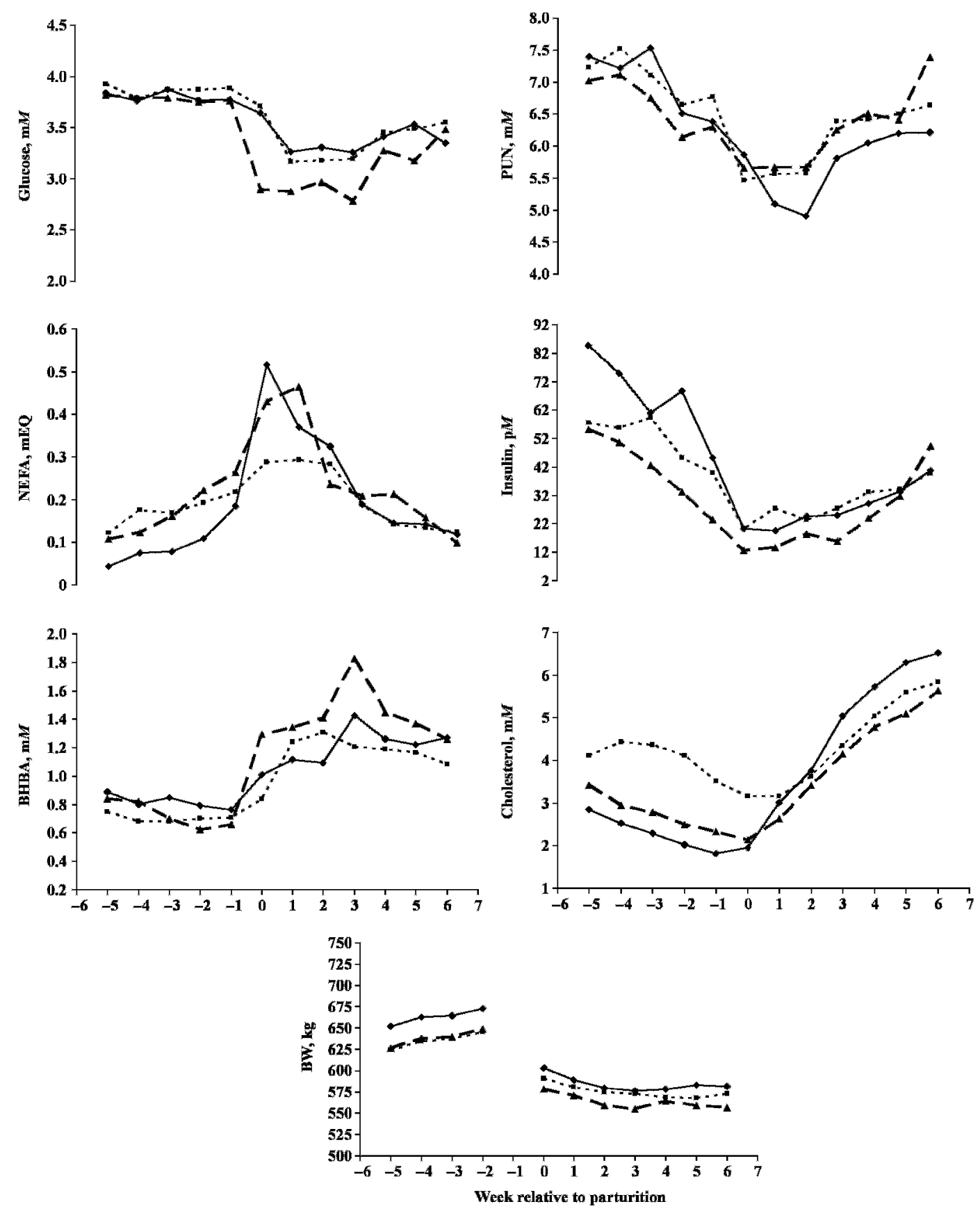

Figure 2. Changes in plasma concentrations of metabolites and insulin. The dairy cows were followed during the period between wk -5 and wk 6 from calving by weekly samplings. Treatments were low-fat feeding in the dry period (dry-control: - - - high saturated fat feeding in the dry period (dry-HSF: ——_ statistical tests.

scribed and evaluated previously (Andersen et al., 2001, 2002a,b). Briefly, before incubation, liver biopsies were blotted onto filter paper, weighed, and subsequently placed in an incubation flask. The biopsies (approximately $20 \mathrm{mg}$ ) were incubated in $1.5 \mathrm{~mL}$ of Earle's Balanced Salt Solution medium containing $1 \mathrm{~m} M$ of palmitate with $2 \mu \mathrm{Ci}\left[1-{ }^{14} \mathrm{C}\right]$ of palmitate and $1 \mathrm{mM} \mathrm{L}$ carnitine in a shaking water bath at $37^{\circ} \mathrm{C}$ and at 60 oscillations per minute for $180 \mathrm{~min}$. Flasks without tissue were incubated as controls. The incubation was terminated by adding $1 \mathrm{~mL}$ of $3 \mathrm{M} \mathrm{HClO}_{4}$. The capacity for complete $\beta$-oxidation of $\left[1-{ }^{14} \mathrm{C}\right]$ palmitate in liver 
tissue was measured as free ${ }^{14} \mathrm{CO}_{2}$. The $\mathrm{CO}_{2}$ produced was collected after the incubation by $0.1 \mathrm{~mL}$ of $2 M$ $\mathrm{NaOH}$ that was injected through a rubber septum onto filter paper placed in a vial hanging in the incubation flasks. Following the addition of $\mathrm{NaOH}$, the flasks were kept at $4^{\circ} \mathrm{C}$ for $1 \mathrm{~h}$ for collection of $\mathrm{CO}_{2}$. The capacity for ketogenesis of $\left[1-{ }^{14} \mathrm{C}\right]$ palmitate was measured as the accumulation of ${ }^{14} \mathrm{C}$ in acid-soluble products (ASP). After addition of $\mathrm{HClO}_{4}$, the radioactivity in a portion of protein-free supernatant was measured as an index of the incorporation of radioactivity into ASP. The ASP were analyzed as described by Grum et al. (1994). The radioactivity in $\mathrm{CO}_{2}$ and $\mathrm{ASP}$ was determined by liquid scintillation counting on a multichannel liquid scintillation counter (LKB Wallac, 1219 Rackbeta, Wallac Danmark A/S, Allerød, Denmark). All incubations were performed in 3 replicates.

\section{Statistical Analyses}

The treatment and week effects on performance, plasma, and liver parameters were analyzed using the REML method of the MIXED procedure (SAS Institute, 1999). The model contained fixed effects of treatments, fixed effects of treatment within lactation state (before calving and after calving), fixed effects of week within lactation state, fixed effects of week within the interaction of treatments and lactation state, and random effect of cow within treatment. For the repeated measurements, the model also contained week from calving within cow. Variables with only postcalving observations, such as milk parameters, were analyzed with the omission of "lactation state" and interactions including "lactation state" in the model. Further, variables with a single observation per cow, such as mobilization parameters, were analyzed with the omission of repeated measures, "week", and interactions including "week" in the model. The covariance structure of repeated measurements yielding the best fit according to Akaike's information criterion or Schwarz' Bayesian criterion was chosen. The variance was homogeneous across individual weeks. The option SLICE under the LSMEANS procedure (SAS Institute, 1999) was used to test effects in situations in which interactions were significant. To obtain a normal distribution of residuals, the plasma concentrations of NEFA, BHBA, and insulin, and milk constituents of protein and SCC, liver $\mathrm{CO}_{2}$ production, and TAG were log-transformed and these variables are reported as the geometric least squares means, but with the standard errors of the log-transformed means. All values are reported as least squares means and standard error of means.

The plasma LCFA data in wk -3 and 3 from calving were subjected to multivariate data analysis on the
LCFA data. A principal components analysis (PCA) was done according to the principle described by Wold et al. (1987) and principal variables were calculated according to Höskuldsson (1994). Both multivariate analyses were performed in the software LatentiX, version 1.00 (Latent5; www.latentix.com).

\section{RESULTS}

\section{Feed Intake and Milk Production}

The effects of treatment and time from calving on feed intake and milk production are shown in Table 4 and Figure 1. Prepartum, DMI and net energy intake were not affected by treatments or week. It is important to remember that the DMI was restricted from wk -5 to calving, and the feeding was planned to provide equal energy among treatments. All cows were fed the same lactation TMR diet in the following early lactation. The DMI increased for all cows $(P<0.0001)$ from calving until the end of the experiment, and no differences $(P=$ 0.18 ) were observed in DMI between the 3 treatments. The average milk yield, fat percentage, protein percentage, and lactose percentage in early lactation were similar among treatments. A week $\times$ treatment interaction $(P<0.0001)$ shows that cows fed dry-HUF had a minor increase in SCC from wk 4 to wk 5 after calving, whereas SCC for cows fed dry-control and dry-HSF continued at a low concentration. All measured milk variables showed a time effect $(P<0.0001)$, which is normal for cows in early lactation (e.g., Andersen et al., 2005).

\section{$B W$ and $B C S$}

The effects of treatment and time from calving on BW and BCS are shown in Table 4 and Figure 2. The average BW and BCS were $634 \pm 39 \mathrm{~kg}$ and $3.6 \pm 0.2$ in wk $-5,588 \pm 24 \mathrm{~kg}$ and $3.3 \pm 0.1$ in wk 0 (after calving $=$ no calf weight), and $570 \pm 44 \mathrm{~kg}$ and $2.6 \pm 0.2$ in wk 5 , respectively. The average BW and BCS changes were $30 \pm 0.2 \mathrm{~kg}$ and $-0.2 \pm 0.1$ in the dry period (wk -5 to -1$)$. The average BW loss and BCS loss were 16 $\pm 13 \mathrm{~kg}$ and $0.53 \pm 0.13$ in early lactation (calving to wk 5). The BW and BCS were not at any time different among treatments, and neither were the changes in BW and BCS in the dry period $(P>0.31)$ and in early lactation $(P>0.62)$.

\section{Plasma Metabolites and Insulin}

Long-chain FA plasma data in wk -3 and wk 3 around calving are presented in Table 5. All measured LCFA (\% of total FA) were affected $(P<0.02)$ by dietary treatment in the dry period (wk -3 ). The multivariate PCA model based on the 7 LCFA measured in wk -3 showed 


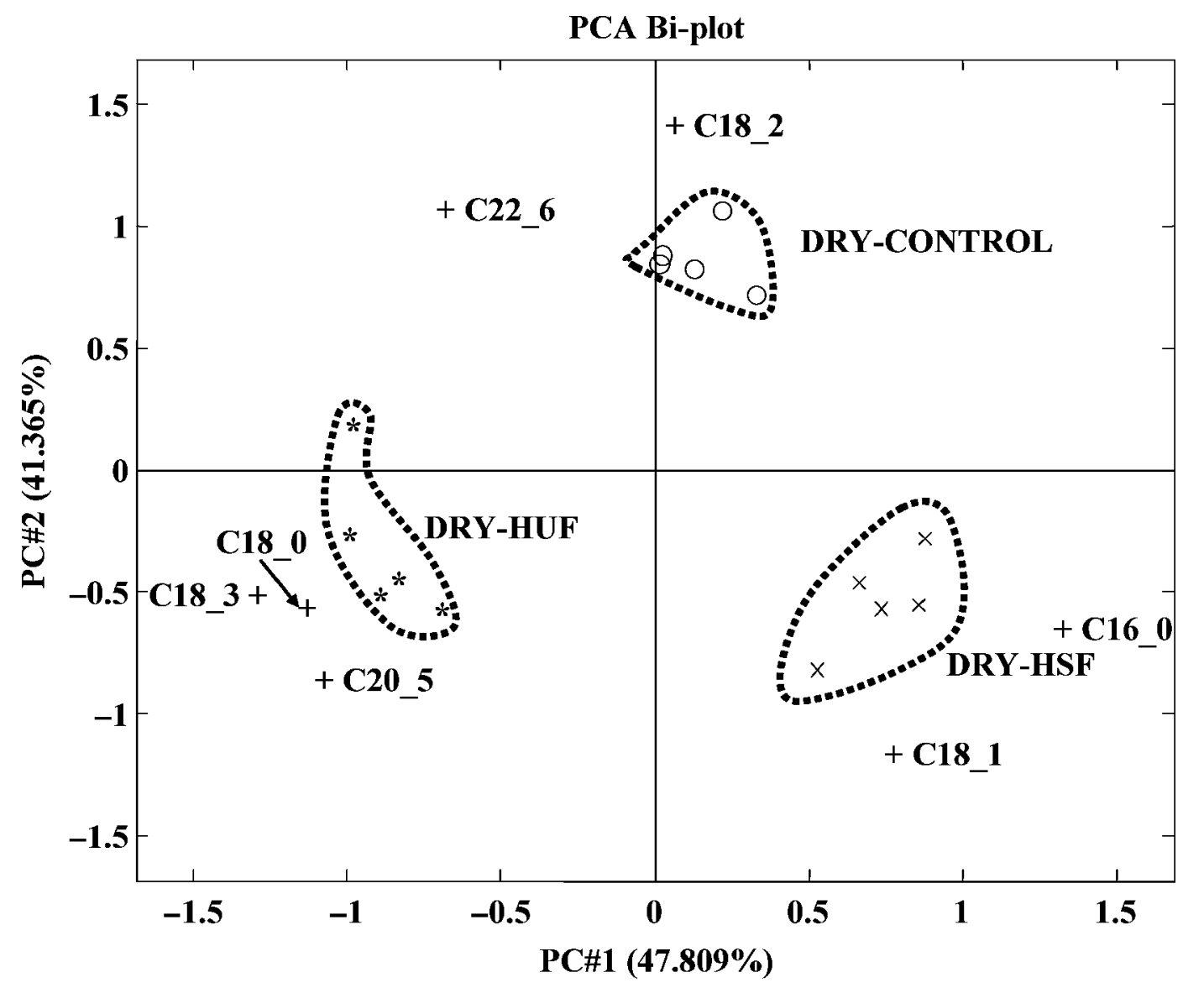

Figure 3. Principal components biplot of the multivariate data analysis on long-chain fatty acids (LCFA) in plasma (\% of total LCFA). The dairy cows were sampled in wk -3 and 3 around calving, and the biplot from wk -3 is shown. Treatments were low-fat feeding in the dry period (dry-control: $\bigcirc$ ), high saturated fat feeding in the dry period (dry-HSF: $\times$ ), or high unsaturated fat feeding in the dry period (dryHUF: *).

(Figure 3 ) that the treatments were clearly separated as indicated by the dotted regions. The PCA biplot revealed that the proportions of $\mathrm{C} 18: 0, \mathrm{C} 18: 3$, and $\mathrm{C} 20: 5$ were positively correlated with cows fed dry-HUF, the proportions of $\mathrm{C} 16: 0$ and $\mathrm{C} 18: 1$ were positively correlated with cows fed dry-HSF, whereas the proportion of C18:2 was positively correlated with cows fed drycontrol. Further, the principal variables analysis showed that cows fed dry-control were characterized primarily by $\mathrm{C} 18: 2$ (86.9\% of the total variance). The cows fed dry-HSF were characterized primarily by C16:0 (84.7\% of the total variance), and the cows fed dry-HUF were characterized primarily by C18:3 (98.4\% of the total variance) in wk -3 multivariate PCA model showed that the treatments could barely be differentiated in the postpartum period (PCA biplot for wk 3 not shown).

Weekly plasma metabolite and insulin data are presented in Table 6 and Figure 2. Plasma glucose concentration was not different among treatments in the pre- partum period. The postcalving plasma glucose concentration was lowest $(P=0.03)$ for the cows fed dry-HUF, and a week $\times$ treatment interaction $(P=0.003)$ showed that the differences were only significant in wk 0 and wk 3 postpartum. Prepartum, the plasma NEFA concentration was greatest $(P<0.0001)$ for cows fed dryHSF and dry-HUF compared with those fed dry-control. A treatment $\times$ week interaction $(P=0.02)$ showed, however, that the differences were not present in the week before calving (wk-1). Further, a week $\times$ treatment interaction $(P=0.02)$ showed that the plasma NEFA concentration in wk 0 and 1 was lowest for cows fed dry-HSF. The plasma NEFA concentration was not affected by treatments from wk 2 to 6 after calving. A week $\times$ treatment $(P=0.04)$ interaction showed a slight decrease in plasma BHBA concentration for cows fed dry-HUF, and a steadier concentration in the prepartum period for cows fed dry-control and dry-HSF. Postpartum, the plasma BHBA concentration was slightly greater for cows fed dry-HUF $(P=0.05)$. Further, a week 
Table 6. The effect of diets containing low fat (dry-control), high saturated fat (dry-HSF), or high unsaturated fat (dry-HUF) on metabolites and insulin in plasma

\begin{tabular}{|c|c|c|c|c|c|c|c|}
\hline \multirow[b]{2}{*}{ Parameter $^{1}$} & \multicolumn{3}{|c|}{ Diet } & \multirow[b]{2}{*}{ SE } & \multicolumn{3}{|c|}{$P$-value ${ }^{2}$} \\
\hline & Dry-control & Dry-HSF & Dry-HUF & & $\mathrm{T}$ & Wk & $\mathrm{T} \times \mathrm{Wk}$ \\
\hline \multicolumn{8}{|c|}{ Glucose, mmol/L } \\
\hline Prepartum $^{3}$ & 3.80 & 3.87 & 3.78 & 0.06 & 0.49 & 0.01 & 0.17 \\
\hline Postpartum $^{4}$ & $3.39^{\mathrm{b}}$ & $3.39^{\mathrm{b}}$ & $3.06^{\mathrm{a}}$ & 0.1 & 0.03 & 0.0003 & 0.003 \\
\hline \multicolumn{8}{|l|}{$\mathrm{NEFA}^{5}{ }^{5} \mu \mathrm{Eq} / \mathrm{L}$} \\
\hline Prepartum & $81.5^{\mathrm{a}}$ & $164.0^{\mathrm{b}}$ & $148.4^{\mathrm{b}}$ & $0.1^{6}$ & $<0.0001$ & $<0.0001$ & 0.02 \\
\hline Postpartum & 200.3 & 164.0 & 200.3 & $0.1^{6}$ & 0.29 & $<0.0001$ & 0.02 \\
\hline \multicolumn{8}{|c|}{$\mathrm{BHBA},{ }^{5} \mathrm{mmol} / \mathrm{L}$} \\
\hline Prepartum & $0.82^{\mathrm{b}}$ & $0.70^{\mathrm{a}}$ & $0.72^{\mathrm{a}}$ & $0.05^{6}$ & 0.04 & 0.001 & 0.04 \\
\hline Postpartum & $1.20^{\mathrm{a}}$ & $1.14^{\mathrm{a}}$ & $1.40^{\mathrm{b}}$ & $0.07^{6}$ & 0.05 & 0.03 & 0.04 \\
\hline \multicolumn{8}{|l|}{$\mathrm{PUN}, \mathrm{mmol} / \mathrm{L}$} \\
\hline Prepartum & 7.00 & 7.05 & 6.66 & 0.24 & 0.43 & $<0.0001$ & 0.84 \\
\hline Postpartum & 5.73 & 6.08 & 6.22 & 0.25 & 0.35 & $<0.0001$ & 0.84 \\
\hline \multicolumn{8}{|c|}{ Calcium, mmol/L } \\
\hline Prepartum & 2.27 & 2.31 & 2.34 & 0.03 & 0.33 & 0.15 & 0.64 \\
\hline Postpartum & 2.43 & 2.43 & 2.46 & 0.03 & 0.33 & 0.0008 & 0.64 \\
\hline \multicolumn{8}{|c|}{ Insulin, ${ }^{5} \mathrm{pmol} / \mathrm{L}$} \\
\hline Prepartum & $65.4^{\mathrm{b}}$ & $51.0^{\mathrm{b}}$ & $39.1^{\mathrm{a}}$ & $0.12^{6}$ & 0.03 & $<0.0001$ & 0.30 \\
\hline Postpartum & 26.8 & 28.8 & 20.9 & $0.13^{6}$ & 0.20 & $<0.0001$ & 0.30 \\
\hline \multicolumn{8}{|c|}{ Cholesterol, $\mathrm{mmol} / \mathrm{L}$} \\
\hline Prepartum & $2.30^{\mathrm{a}}$ & $4.11^{\mathrm{b}}$ & $2.79^{\mathrm{a}}$ & 0.30 & $<0.0001$ & $<0.0001$ & $<0.0001$ \\
\hline Postpartum & 4.61 & 4.40 & 3.97 & 0.30 & 0.30 & $<0.0001$ & $<0.0001$ \\
\hline \multicolumn{8}{|l|}{ GGT, U/I } \\
\hline Prepartum & 19.4 & 22.4 & 19.7 & 1.7 & 0.33 & 0.02 & 0.60 \\
\hline Postpartum & 21.1 & 23.4 & 22.3 & 1.7 & 0.55 & $<0.0001$ & 0.60 \\
\hline \multicolumn{8}{|l|}{ AST, U/I } \\
\hline Prepartum & 67.9 & 77.4 & 70.2 & 3.5 & 0.11 & 0.04 & 0.67 \\
\hline Postpartum & 92.0 & 87.5 & 88.9 & 4.5 & 0.72 & $<0.0001$ & 0.67 \\
\hline
\end{tabular}

a,b Means with different superscripts within a row indicate a $P$-value $<0.05$.

${ }^{1} \mathrm{PUN}=$ plasma urea nitrogen; GGT $=\gamma$-glutamyl transferase; $\mathrm{AST}=$ aspartate aminotransferase.

${ }^{2} \mathrm{~T}=$ treatment in dry period; $\mathrm{Wk}=$ week around calving.

${ }^{3} \mathrm{LSM}$ of wk -5 to -1 .

${ }^{4} \mathrm{LSM}$ of wk 0 to 5 .

${ }^{5}$ Geometric mean of log-transformed data.

${ }^{6} \mathrm{SE}$ based on log-transformed data.

$\times$ treatment interaction $(P=0.04)$ showed a sudden increase in plasma BHBA concentration between wk 2 and 3 for cows fed dry-control and dry-HUF. Plasma urea $\mathrm{N}$ and calcium concentrations were similar among treatments, both prepartum and postpartum. Plasma insulin concentration was lowest $(P=0.03)$ in the prepartum period for cows fed dry-HUF. Postpartum, there were no differences among treatments in plasma insulin concentration. The cholesterol concentration in the prepartum period was greatest $(P<0.0001)$ for the cows fed dry-HSF. Furthermore, a week $\times$ treatment interaction $(P<0.0001)$ showed a slightly different development in the cholesterol concentration in the early stage of the prepartum period for the cows fed dry-HSF compared with the cows fed dry-control and dry-HUF. Postpartum, a week $\times$ treatment interaction $(P<0.0001)$ showed that cows fed dry-HSF had the greatest plasma cholesterol concentration in the actual week of calving, followed by no further differences between the treatments. Plasma concentrations of GGT and AST were similar among treatments at any time in the experimental period. All measured plasma metabolites and hormones showed a time effect, which is normal for cows in the periparturient period (e.g., Andersen et al., 2005).

\section{Hepatic Chemical Composition and LCFA Metabolism}

Figure 4 and Table 7 summarize the data on hepatic TAG and glycogen concentration and capacity of LCFA $\beta$-oxidation. A week $\times$ treatment interaction $(P=0.05)$ showed that the hepatic TAG concentration was lowest in wk 2 postpartum for cows fed dry-HSF compared with the other treatments, and there were no differences among treatments in the other weeks. A tendency 

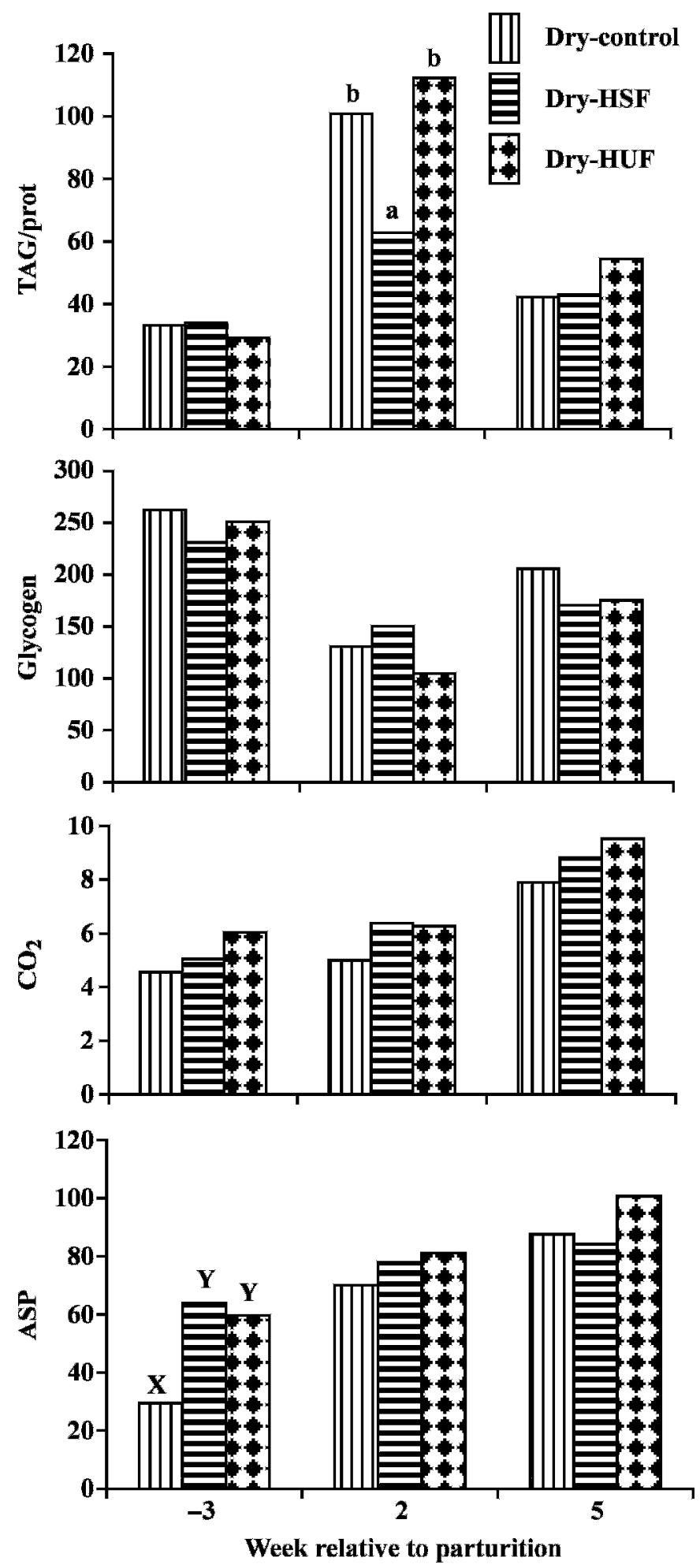

Figure 4. Changes in liver triacylglycerol (TAG), glycogen, complete palmitate $\beta$-oxidation capacity $\left(\mathrm{CO}_{2}\right)$ and incomplete palmitate $\beta$-oxidation capacity (acid-soluble products, ASP). XY is a tendency $(P<0.07)$; ab is significantly different $(P<0.05)$. See Table 7 for statistical tests. to a week $\times$ treatment interaction $(P<0.07)$ showed that cows fed dry-HSF and dry-HUF had the greatest capacity for incomplete LCFA $\beta$-oxidation capacity (ASP) in the prepartum period (wk-3). No significant treatment effects were observed on hepatic glycogen concentration or on the hepatic complete $\beta$-oxidation capacity at any time. All measured liver parameters showed time effects $(P<0.0001)$, as previously reported in the literature (Andersen et al., 2002b, 2005; Douglas et al., 2004).

\section{DISCUSSION}

It is known that feedstuffs high in fat content can have low palatability for dairy cows. Therefore, we performed a pilot study to evaluate palatability and visual digestive side effects (e.g., diarrhea) of feed components of potential interest for the present experiment. The pilot study showed that linseed (high in C18:3) is very palatable for dairy cows without side effects. A saturated fat source, Lipitec Bovi LM, was chosen because of its large concentration of C16:0 and stearic acid (C18:0) and because this fat source was highly palatable for the cows without detected side effects. Further, the pilot study demonstrated that there was no significant feed refusal in the prepartum period. Lipitec, in the amount of $600 \mathrm{~g} / \mathrm{d}$, was added to the dry-HSF feed. Lipitec contains approximately $2 \%$ lecithin (phosphatidylcholine, a phosphoglyceride that contains $2 \mathrm{FA}$ and 1 choline), and choline represented a daily intake of approximately $2.2 \mathrm{~g}$ for these cows. Several studies have demonstrated that choline affects liver TAG content in monogastric animals (Buang et al., 2005). Further, choline (rumenprotected) has been tested in dairy cows in the periparturient period, and it has been implied that choline may decrease the hepatic capacity to store esterified products, increase the glycogen concentration in the liver, and increase the rate of very low density lipoprotein production and secretion from the liver (Piepenbrink and Overton, 2003). The experiment of Piepenbrink and Overton (2003) demonstrated a positive effect on liver glycogen when the cows were supplemented with more than $15 \mathrm{~g}$ of choline per day. The $2.2 \mathrm{~g} / \mathrm{d}$ of choline available for the cows fed dry-HSF was considerably lower than has been tested in previous experiments, in which the effect has been proved to be positive. Consequently, it seems reasonable to exclude possible effects of choline for cows fed dry-HSF.

Prepartum plasma showed a distinct difference in both total NEFA concentration and specific LCFA data. Cows fed dry-HSF and dry-HUF had the greatest plasma NEFA concentrations, and cows fed dry-HSF were characterized by the greatest relative percentage of $16: 0$. Further, cows fed dry-HUF were characterized 
Table 7. Statistical tests of liver triacylglycerol (TAG), glycogen, complete palmitate $\beta$-oxidation capacity $\left(\mathrm{CO}_{2}\right)$, and incomplete palmitate $\beta$-oxidation capacity (ASP)

\begin{tabular}{lcccc}
\hline Parameter & $\mathrm{SE}$ & $\mathrm{T}^{1}$ & $\mathrm{Wk}^{2}$ & $\mathrm{~T} \times \mathrm{Wk}$ \\
\hline TAG, $\mu \mathrm{mol} / \mathrm{g}$ of total protein & $0.09^{3}$ & 0.17 & $<0.0001$ & 0.05 \\
Glycogen, $\mu$ mol/g of tissue & 14 & 0.51 & $<0.0001$ & 0.27 \\
$\mathrm{CO}_{2}, \mathrm{nmol} / \mathrm{g}$ of tissue per $\mathrm{h}$ & $0.09^{3}$ & 0.22 & $<0.0001$ & 0.87 \\
Acid-soluble products (ASP), nmol/g of tissue per $\mathrm{h}$ & 7.9 & 0.26 & $<0.0001$ & 0.07 \\
\hline
\end{tabular}

\footnotetext{
${ }^{1} \mathrm{~T}=$ treatment in dry period (Dry-control = low fat; Dry-HSF = high saturated fat; and Dry-HUF = high unsaturated fat). See Figure 4 for weekly data.

${ }^{2} \mathrm{Wk}=$ week around calving $(\mathrm{wk}-3,2$, and 5$)$.

${ }^{3} \mathrm{SE}$ based on log-transformed data.
}

by the greatest relative percentage of $\mathrm{C} 18: 3$ in the prepartum plasma samples, demonstrating that the dietary treatments were accessible for the general metabolism.

\section{Effects of Feeding Fat Sources in the Dry Period on Periparturient DMI and Milk Production}

The cows in the present experiment were fed according to requirements (i.e., restrictedly fed), and there were no differences in DMI or energy intake among treatments in the prepartum period. Further, cows approaching calving had no significant decrease in DMI, which has been shown before for dry cows fed according to requirements (Kunz et al., 1985). Postpartum DMI, milk yield, and milk composition were not affected by dietary treatment in the dry period. No significant effects of high-fat feeding of dry cows on performance in the following early lactation have been shown before (Grum et al., 1996b; Douglas et al., 2004, 2006).

\section{Effects of Feeding Fat Sources in the Dry Period on Metabolic Parameters Prepartum}

Prepartum plasma concentrations of NEFA, BHBA, insulin, and cholesterol and liver ASP production capacity were affected by the dietary treatments, despite the similar prepartum DMI and energy intake. The prepartum NEFA concentration in plasma was more than $45 \%$ greater for the 2 fat-supplemented treatments compared with the control cows. Previously, Grum et al. (1996b) demonstrated significantly greater prepartum NEFA concentrations in plasma as an effect of high-fat feeding in the dry period. The greater prepartum NEFA concentration was, however, correlated with a significantly lower DMI and energy intake for cows fed a high-fat diet (Grum et al., 1996b). Results from several experiments indicate that a reduction in energy intake in the dry period is the most efficient way of increasing plasma NEFA concentration in the prepartum period (Kunz et al., 1985; Grum et al., 2002; Douglas et al., 2004, 2006). Cows fed supplemented fat in the dry period had the greatest plasma NEFA concentration and the lowest plasma BHBA concentration in the present experiment. Moreover, the cows fed dry$\mathrm{HSF}$ and dry-HUF showed a tendency to increased capacity for hepatic ASP production (including BHBA production) in the prepartum period. That fat feeding in the dry period does not increase the prepartum BHBA concentration in plasma has been demonstrated before (Grum et al., 1996b; Douglas et al., 2004, 2006). The lower plasma BHBA concentration in fat-supplemented cows could be explained by the relatively smaller carbohydrate intake compared with the control cows. The prepartum glucose concentration in plasma was not affected by treatments, and there were no differences in plasma insulin concentration between control cows and cows fed dry-HSF. On the contrary, plasma insulin concentration in the dry period was lowest for cows fed dry-HUF. Negative (Grum et al., 1996b) or no effect (Douglas et al., 2004, 2006) of feeding fat to nonlactating dairy cows on plasma insulin have been demonstrated. Further, Mashek et al. (2005) demonstrated that cows intravenously supplied with linseed oil had the lowest insulin concentration in plasma compared with cows intravenously supplied with tallow. Different LCFA and different combinations of LCFA can affect the capacity for gluconeogenesis in ruminant hepatocytes (Mashek et al., 2002; Mashek and Grummer, 2003). This, however, is not likely to be the explanation for different concentrations of insulin, because of the similar prepartum plasma glucose concentrations among treatments. A more plausible explanation could be that linseed affected insulin metabolism, especially insulin secretion, because it has been demonstrated that different FA profiles can affect glucose-induced insulin secretion (Xiao et al., 2006). Further, a low insulin concentration could indicate that cows fed dry-HUF had the lowest energy balance compared with cows on the other treatments. None of the other measured parameters in the prepartum period, however, support this indication.

Cows fed dry-HSF had a plasma cholesterol concentration more than $60 \%$ greater than the control cows. Previously, it has been shown that an increasing 
amount of LCFA reaching the small intestine of dairy cows increases cholesterol in plasma (Bremmer et al., 1998; Douglas et al., 2004). The cows fed dry-HUF were not different, however, from the control cows in the plasma cholesterol concentration in the prepartum period. This indicates either that restrictedly fed dry cows have high cholesterol concentrations in plasma, as shown by Douglas et al. (2006), or that LCFA from linseed altered cholesterol clearance or lipoprotein metabolism in these cows. Cholesterol metabolism in dairy cows is not well understood, but experiments have confirmed that the cholesterol concentration in milk and plasma decreases in connection with feeding linseed (Petit, 2002; Reklewska et al., 2002). Even with the greater plasma NEFA concentration for the 2 fat-supplemented treatments, there were no differences in liver TAG concentration in the liver prepartum. A high plasma NEFA concentration is most often not associated with increased liver TAG concentration in the week before calving (Grum et al., 1996b; Murondoti et al., 2004; Douglas et al., 2006). Prepartum, cows fed dry-HSF and dry-HUF had a tendency to a greater hepatic ASP production capacity compared with the control cows. This could be argued as a possible explanation for the lack of a greater liver TAG concentration prepartum for these cows. Previously, it has been demonstrated that a high prepartum plasma NEFA concentration stimulates hepatic LCFA $\beta$-oxidation capacity (Grum et al., 1996b) and decreases hepatic TAG concentration in the week of calving (Grum et al., 1996b; Douglas et al., 2006). Further, in vitro studies have demonstrated a stimulating effect of increased FA on the hepatic capacity for ASP production in bovine hepatocytes (Cadorniga-Valino et al., 1997; Mashek and Grummer, 2003). Therefore, it is estimated that the generally greater NEFA concentration in plasma, and not a specific fat source fed to dry cows, was the main factor in the increased capacity of incomplete LCFA $\beta$-oxidation in the liver. It is therefore possible to reject the hypothesis for the present study - that cows fed dry-HUF would have the greatest prepartum capacity of LCFA $\beta$-oxidation in the liver. The possible effects and mechanisms of different LCFA, both on hepatic carbohydrate and lipid metabolism for ruminants, seem to be neither simple nor identical (Mashek et al., 2002, 2005; Petit, 2002, 2003; Mashek and Grummer, 2003). Further, it seems clear that the ruminant liver is very different compared with the rat liver in relation to lipid metabolism (Grum et al., 1994).

\section{Effects of Feeding Fat Sources in the Dry Period on Priming for Body Mobilization in the Following Early Lactation}

Plasma glucose and NEFA concentrations in the first week of lactation and hepatic TAG concentration in wk
2 after calving showed significant and clear biological prepartum treatment effects. Cows fed dry-HSF had the lowest plasma NEFA concentration and the lowest liver TAG concentration compared with cows fed dryHUF and control cows in the first 2 wk of lactation. Therefore, it is clear that cows fed dry-HSF were those that had been positively primed for body mobilization in the periparturient period. These results seem to be in line with previous results demonstrated by Grum et al. (1996b). The lower hepatic TAG concentration in wk 2 after calving was not correlated with a greater capacity for hepatic LCFA $\beta$-oxidation. Therefore, the lower hepatic TAG concentration can mainly be explained by the lower NEFA concentration in plasma. Our hypothesis was, however, that the cows fed dryHUF should have been significantly primed for body mobilization in the following early lactation. Apparently, the dry-HUF cows did not show any positive effect in early lactation; on the contrary, these cows had the lowest plasma glucose concentration in early lactation. An explanation of the apparent negative effect of feeding linseed in the dry period is not straightforward. It is clear that different FA affect both lipid and carbohydrate metabolism in most mammals. It also seems clear that specific FA can have different effects in different species, but also as an interaction with both physiological and reproductive stage (Chilliard, 1993).

Including results from 3 other studies (Grum et al., 1996b; Douglas et al., 2004, 2006), it seems possible to conclude that an increased NEFA concentration in plasma in the last $5 \mathrm{wk}$ (approximately) of the dry period is an important factor in priming for body mobilization in the following early lactation. A mechanistic explanation of this, however, is not found or is impossible to explain.

Body weight and BCS were not affected by treatment in the dry period or early lactation, despite the differences in both plasma NEFA concentration and liver TAG concentration in the first week of lactation. That BW and BCS changes in early lactation (the first 3 to 5 wk after calving) are difficult to alter, and that BW and BCS changes do not correlate with classic metabolic parameters in blood and liver have been demonstrated previously (Driver et al., 1990; Beam and Butler, 1997; Andersen et al., 2004, 2005; Boken et al., 2005). This indicates that metabolic imbalance is not a simple function of changes in BW and BCS in the periparturient period.

\section{CONCLUSIONS}

A successful dry-cow strategy to prime for body mobilization in the periparturient period is associated with a significantly greater NEFA concentration in the pre- 
partum period. Feeding a large amount of linseed (high in $\mathrm{C} 18: 3)$ in the dry period was not beneficial for the metabolic balance of dairy cows in the periparturient period. On the contrary, data indicate that the best FA to feed in the dry period for priming for body mobilization are C16:0 and C18:0.

\section{ACKNOWLEDGMENTS}

The Danish Veterinary and Agricultural Research Council and the Danish Cattle Association provided financial support for this study. The authors wish to thank Ellen-Margrethe Vestergaard, DVM, for taking liver biopsies. Furthermore, we want to thank the following laboratory technicians at the Danish Institute of Agricultural Sciences for their skillful help during sampling and analysis of samples: D. Agnholt, L. Niklassen, J. B. Clausen, C. Bertelsen, and J. Adamsen. For proofreading the manuscript, we thank K. V. Østergaard.

\section{REFERENCES}

Andersen, J. B., N. C. Friggens, T. Larsen, M. V. Vestergaard, and K. L. Ingvartsen. 2004. Effect of energy density in the diet and milking frequency on plasma metabolites and hormones in early lactation dairy cows. J. Vet. Med. A. 51:52-57.

Andersen, J. B., T. Larsen, and K. L. Ingvartsen. 2001. Evaluation of tissue preparation for in vitro hepatic LCFA metabolism. Acta Agric. Scand. Anim. Sci. 51:47-52.

Andersen, J. B., T. Larsen, M. O. Nielsen, and K. L. Ingvartsen. 2002b. Effect of energy density in the diet and milking frequency on hepatic long chain fatty acid oxidation in early lactating dairy cows. J. Vet. Med. A. 49:177-183.

Andersen, J. B., T. G. Madsen, T. Larsen, K. L. Ingvartsen, and M. O. Nielsen. 2005. The effects of dry period versus continuous lactation on metabolic status and performance in periparturient cows. J. Dairy Sci. 88:3530-3541.

Andersen, J. B., D. G. Mashek, T. Larsen, M. O. Nielsen, and K. L. Ingvartsen. 2002a. Effects of hyperinsulinemia under euglycemic condition on liver fat metabolism in dairy cows in early and midlactation. J. Vet. Med. A. 49:65-71.

Beam, S. W., and W. R. Butler. 1997. Energy balance and ovarian follicle development prior to the first ovulation postpartum in dairy cows receiving three levels of dietary fat. Biol. Reprod. 56:133-142.

Bell, A. W. 1995. Regulation of organic nutrient metabolism during transition from late pregnancy to early lactation. J. Anim. Sci. 73:2804-2819.

Berge, R. K., L. Madsen, H. Vaagenes, K. J. Tronstad, M. Gottlicher, and A. C. Rustan. 1999. In contrast with docosahexaenoic acid, eicosapentaenoic acid and hypolipidaemic derivatives decrease hepatic synthesis and secretion of triacylglycerol by decreased diacylglycerol acyltransferase activity and stimulation of fatty acid oxidation. Biochem. J. 343:191-197.

Boken, S. L., C. R. Staples, L. E. Sollenberger, T. C. Jenkins, and W. W. Thatcher. 2005. Effect of grazing and fat supplementation on production and reproduction of Holstein cows. J. Dairy Sci. 88:4258-4272.

Bremmer, D. R., L. D. Ruppert, J. H. Clark, and J. K. Drackley. 1998. Effects of chain length and unsaturation of fatty acid mixtures infused into the abomasum of lactating dairy cows. J. Dairy Sci. $81: 176-188$
Buang, Y., Y. M. Wang, J. Y. Cha, K. Nagao, and T. Yanagita. 2005. Dietary phosphatidylcholine alleviates fatty liver induced by orotic acid. Nutrition 21:867-873.

Cadorniga-Valino, C., R. R. Grummer, L. E. Armentano, S. S. Donkin, and S. Bertics. 1997. Effects of fatty acids and hormones on fatty acid metabolism and gluconeogenesis in bovine hepatocytes. J. Dairy Sci. 80:646-656.

Chilliard, Y. 1993. Dietary fat and adipose tissue metabolism in ruminants, pigs, and rodents: A review. J. Dairy Sci. 76:3897-3931.

Douglas, G. N., T. R. Overton, H. G. Bateman, H. M. Dann, and J. K. Drackley. 2006. Prepartal plane of nutrition, regardless of dietary energy source, affects periparturient metabolism and dry matter intake in Holstein cows. J. Dairy Sci. 89:2141-2157.

Douglas, G. N., T. R. Overton, H. G. Bateman, and J. K. Drackley. 2004. Peripartal metabolism and production of Holstein cows fed diets supplemented with fat during the dry period. J. Dairy Sci. 87:4210-4220.

Drackley, J. K., and J. B. Andersen. 2006. Splanchnic metabolism of long-chain fatty acids in ruminants. Pages 199-224 in Ruminant physiology: Digestion, metabolism and impact of nutrition on gene expression, immunology and stress. K. Sejrsen, T. Hvelplund and M. O. Nielsen, ed. Wageningen Academic Publishers, Wageningen, the Netherlands.

Driver, L. S., R. R. Grummer, and L. H. Schultz. 1990. Effects of feeding heat-treated soybeans and niacin to high producing cows in early lactation. J. Dairy Sci. 73:463-469.

Friggens, N. C., J. B. Andersen, T. Larsen, O. Aaes, and R. J. Dewhurst. 2004. Priming the dairy cow for lactation: A review of dry cow feeding strategies. Anim. Res. 53:453-473.

Grum, D. E., J. K. Drackley, and J. H. Clark. 2002. Fatty acid metabolism in liver of dairy cows fed supplemental fat and nicotinic acid during an entire lactation. J. Dairy Sci. 85:3026-3034.

Grum, D. E., J. K. Drackley, L. R. Hansen, and J. D. J. Cremin. 1996a. Production, digestion, and hepatic lipid metabolism of dairy cows fed increased energy from fat or concentrate. J. Dairy Sci. 79:1836-1849.

Grum, D. E., J. K. Drackley, R. S. Younker, D. W. Lacount, and J. J. Veenhuizen. 1996b. Nutrition during the dry period and hepatic lipid metabolism of periparturient dairy cows. J. Dairy Sci. 79:1850-1864.

Grum, D. E., L. R. Hansen, and J. K. Drackley. 1994. Peroxisomal beta-oxidation of fatty acids in bovine and rat liver. Comp. Biochem. Physiol. 109B:281-292.

Hagemeister, H., D. Precht, M. Franzen, and C. A. Barth. 1991. $\alpha-$ Linolenic acid transfer into the milk fat and its elongation by cows. Fat Sci. Technol. 93:387-391.

Höskuldsson, A. 1994. The H-principle-New ideas, algorithms and methods in applied-mathematics and statistics. Chemomet. Intellig. Lab. Methods 23:1-28.

Ide, T., M. Murata, and M. Sugano. 1996. Stimulation of the activities of hepatic fatty acid oxidation enzymes by dietary fat rich in $\alpha$ linolenic acid in rats. J. Lipid Res. 37:448-463.

Ingvartsen, K. L., O. Aaes, and J. B. Andersen. 2001. Effects of pattern of concentrate allocation in the dry period and early lactation feed intake and lactational performance in dairy cows. Livest. Prod. Sci. 71:207-221.

Ingvartsen, K. L., and J. B. Andersen. 2000. Integration of metabolism and intake regulation: A review focusing on periparturient animals. J. Dairy Sci. 83:1573-1597.

Ingvartsen, K. L., R. J. Dewhurst, and N. C. Friggens. 2003. On the relationship between lactational performance and health: Is it yield or metabolic imbalance that cause production diseases in dairy cattle? Livest. Prod. Sci. 83:277-308.

Jørgensen, H., V. M. Gabert, M. S. Hedemann, and S. K. Jensen. 2000. Digestion of fat does not differ in growing pigs fed diets containing fish oil, rapeseed oil or coconut oil. J. Nutr. 130:852-857.

Kerner, J., and C. Hoppel. 2000. Fatty acid import into mitochondria. Biochim. Biophys. Acta 1486:1-17.

Kristensen, T. 1986. Method for estimation of body condition of dairy cattle. Pages 59-75 in Research in cattle production systems. 
Østergaard, V., and J. Hindhede, ed. Report No. 615. Research Centre Foulum, Natl. Inst. Anim. Sci., Denmark. (In Danish)

Kunz, P. L., J. W. Blum, I. C. Hart, H. Bickel, and J. Landis. 1985. Effects of different energy intakes before and after calving on food intake, performance and blood hormones and metabolites in dairy cows. Anim. Prod. 40:219-231.

Lessard, M., N. Gagnon, and H. V. Petit. 2003. Immune response of postpartum dairy cows fed flaxseed. J. Dairy Sci. 86:2647-2657.

Mashek, D. G., S. J. Bertics, and R. R. Grummer. 2002. Metabolic fate of long-chain unsaturated fatty acids and their effects on palmitic acid metabolism and gluconeogenesis in bovine hepatocytes. J. Dairy Sci. 85:2283-2289.

Mashek, D. G., S. J. Bertics, and R. R. Grummer. 2005. Effects of intravenous triacylglycerol emulsions on hepatic metabolism and blood metabolites in fasted dairy cows. J. Dairy Sci. 88:100-109.

Mashek, D. G., and R. R. Grummer. 2003. Effects of long chain fatty acids on lipid and glucose metabolism in monolayer cultures of bovine hepatocytes. J. Dairy Sci. 86:2390-2396.

Mashek, D. G., K. L. Ingvartsen, J. B. Andersen, M. Vestergaard, and T. Larsen. 2001. Effects of a four-day hyperinsulinemic-euglycemic clamp in early and mid-lactation dairy cows on plasma concentrations of metabolites, hormones, and binding proteins. Domest. Anim. Endocrinol. 21:169-185.

Murondoti, A., R. Jorritsma, A. C. Beynen, T. Wensing, and M. J. H. Geelen. 2004. Unrestricted feed intake during the dry period impairs the postpartum oxidation and synthesis of fatty acids in the liver of dairy cows. J. Dairy Sci. 87:672-679.

Nielsen, N. I., N. C. Friggens, T. Larsen, J. B. Andersen, M. O. Nielsen, and K. L. Ingvartsen. 2007. Effect of changes in diet energy density on feed intake, milk yield and metabolic parameters in dairy cows in early lactation. Animal 1:335-346.

Osmundsen, H., J. Bremer, and J. I. Pedersen. 1991. Metabolic aspects of peroxisomal $\beta$-oxidation. Biochim. Biophys. Acta 1085:141-158

Petit, H. V. 2002. Digestion, milk production, milk composition, and blood composition of dairy cows fed whole flaxseed. J. Dairy Sci. $85: 1482-1490$

Petit, H. V. 2003. Digestion, milk production, milk composition, and blood composition of dairy cows fed formaldehyde treated flaxseed or sunflower seed. J. Dairy Sci. 86:2637-2646.
Piepenbrink, M. S., and T. R. Overton. 2003. Liver metabolism and production of cows fed increasing amounts of rumen-protected choline during the periparturient period. J. Dairy Sci. 86:17221733.

Reklewska, B., A. Oprzadek, Z. Reklewski, L. Panicke, B. Kuczynska, and J. Oprzadek. 2002. Alternative for modifying the fatty acid composition and decreasing the cholesterol level in the milk of cows. Livest. Prod. Sci. 76:235-243.

Rochrame, F. 1967. An enzymatic and fluorometric method for estimating urea concentrations in nanoliter specimens. Anal. Biochem. 21:372-381.

SAS Institute. 1999. SAS Online Doc, version 8. SAS Institute Inc., Cary, NC.

Schoonjans, K., B. Staels, and J. Auwerx. 1996. The peroxisome proliferator activated receptors (PPARs) and their effects on lipid metabolism and adipocyte differentiation. Biochem. Biophys. Acta 1302:93-109.

Shaw, L. M., J. H. Strømme, J. L. Loudon, and L. Theodosen. 1983. IFCC methods for the measurement of catalytic concentration of enzymes. Part 4 IFCC method for $\gamma$-glutamyltransferase. J. Clin. Chem. Biochem. 21:633-646.

Sjaunja, L. O., L. Baevre, L. Junkkarinen, J. Pedersen, and J. Setälä. 1990. A Nordic proposal for an energy corrected milk (ECM) formula. Pages 156-157 in EAAP publication 50. Centre for Agricultural Publishing and Documentation (PUDOC), Wageningen, the Netherlands.

Strudsholm, F., O. Aaes, J. Madsen, V. F. Kristensen, H. R. Andersen, T. Hvelplund, and S. Østergaard. 1999. Danish Feeding Recommendations for Cattle. Report No. 84. Natl. Dept. Cattle Husbandry, Skejby, Denmark. (In Danish)

Strudsholm, F., E. S. Skovbo, J. C. Flye, A. M. Kjeldsen, M. Weisbjerg, K. Søegaard, V. F. Kristensen, T. Hvelplund, and J. E. Hermansen. 1997. Feed Tables. Report No. 69. Natl. Dept. Cattle Husbandry, Skejby, Denmark. (In Danish)

Wold, S., K. Esbensen, and P. Geladi. 1987. Principal Component Analysis. Chemomet. Intellig. Lab. Syst. 2:37-52.

Xiao, C., A. Giacca, A. Carpentier, and G. F. Lewis. 2006. Differential effects of monosaturated, polusaturated and saturated fat ingestion on glucose-stimulated insulin secretion, sensitivity and clearance in overweight and obese, non-diabetic humans. Diabetologia 49:1371-1379. 